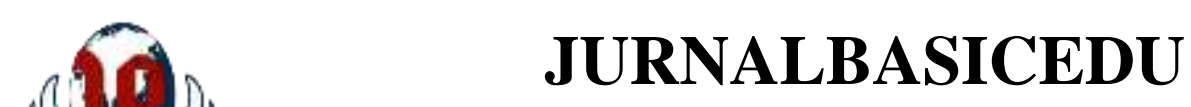

Volume 6 Nomor 1 Tahun 2022 Halaman 1311 - 1323

Research \& Learningin Elementary Education

https://jbasic.org/index.php/basicedu

\title{
Pengaruh Model Pembelajaran Snowball throwing Terhadap Kemampuan Aspek Kognitif dan Motorik Anak Usia Dini
}

\author{
Lasma Roha Sitompul ${ }^{1}$, Tien Rafida ${ }^{2}$, Humaidah Br. Hasibuan ${ }^{3 凶}$ \\ Universitas Islam Negeri Sumatera Utara, Indonesia ${ }^{1,2,3}$ \\ E-mail: 1asmamoto@gmail.com ${ }^{1}$, tienrafida@uinsu.ac.id ${ }^{2}, \underline{\text { humaidahhasibuan@uinsu.ac.id }}^{3}$
}

\begin{abstract}
Abstrak
Pendidikan yang baik dan benar kepada anak, dapat dimulai dari pendidikan anak usia dini. Ditemukan beberapa permasalah terkait fasilitas bermain anak belum memadai untuk perkembangan motorik anak usia dini, tenaga pendidik masih didominasi yang tidak sesuai jurusan dengan pendidikan anak usia dini, dan model pembelajran yang belum bervariasi. Tujuan penelitian ini untuk mengetahui pengaruh terhadap model pembelajaran snowball throwing pada kemampuan aspek kognitif dan motorik anak usia dini di RA Aisyah Az Zahra Medan Johor, Penelitian ini adalah penelitian kuantitatif eksperimen. Jenis penelitian yang digunakan adalah True Experimental design. Populasi dalam penelitian ini ialah seluruh jumlah murid RA Aisya Az Zahra sebanyak 65 orang. Teknik pengambilan sampel yang digunakan peneliti adalah teknik purposive sampling. Kelas yang digunakan dalam penelitian ini adalah siswa kelas A yang berjumlah 30 siswa sebagai kelas kontrol dan kelas B sebagai kelas eksperimen yang berjumlah 30 siswa. Desain penelitian yang digunakan dalam penelitian ini adalah Pretest- Postest Control Group Design. Hasil terdapat pengaruh pada kemampuan aspek kognitif dan kemampuan aspek motorik model pembelajaran snowball throwing. Diperoleh nilai aspek kognitif $\mathrm{t}$ hitung $=6,44$ maka thitung $>$ ttabel $(6,44>2,093)$ dan nilai aspek aspek $\mathrm{t}$ hitung $=5,96$ maka thitung $>$ ttabel $(5,96>2,093)$.
\end{abstract}

Kata Kunci: Model Pembelajaran, Snowball throwing, Aspek Kognitif, Aspek Motorik

\begin{abstract}
Good and correct education children, can be started from early childhood education. Found that several problems related children's play facilities were not sufficient for early childhood motoric development, educators were still dominated by those that were not in accordance with field of early childhood education, and learning models that did not vary. Purpose of this study was to determine effect of snowball throwing learning model on cognitive and motor skills of early childhood at RA AISYAH Az Zahra Medan Johor. This research is an experimental quantitative study. The type of research used is True Experimental design. Population in this study total number of students of RA Aisya Az Zahra as many 65 people. Sampling technique used by researcher is purposive sampling technique. Class used in this study class A students who collected 30 students as control class and class B as experimental class which collected 30 students. Research design used in this study was Pretest-Potest Control Group Design. Results effect on ability of the cognitive aspect and ability motor aspect snowball throwing learning model. Value of cognitive aspect $t$ count $=6.44$, then tcount > ttable (6.44>2.093) and aspect value of t-count $=5.96$, then tcount $>$ ttable $(5.96>2.093)$.
\end{abstract}

Keywords: Learning Model, Snowball throwing, Cognitive Aspect, Motor Aspect.

Copyright (c) 2022 Lasma Roha Sitompul, Tien Rafida, Humaidah Br. Hasibuan

$\triangle$ Corresponding author :

Email : humaidahhasibuan@uinsu.ac.id

DOI $\quad:$ https://doi.org/10.31004/basicedu.v6i1.2152

ISSN 2580-3735 (Media Cetak)

ISSN 2580-1147 (Media Online)

Jurnal Basicedu Vol 6 No 1 Tahun 2022 p-ISSN 2580-3735 e-ISSN 2580-1147 
1312 Pengaruh Model Pembelajaran Snowball Throwing Terhadap Kemampuan Aspek Kognitif dan Motorik Anak Usia Dini - Lasma Roha Sitompul, Tien Rafida, Humaidah Br. Hasibuan

DOI: https://doi.org/10.31004/basicedu.v6i1.2152

\section{PENDAHULUAN}

Usia dini merupakan masa yang paling baik dan tepat untuk menanamkan nilai-nilai kebaikan yang ada, karena anak sedang berada pada tahap pertumbuhan dan perkembangan baik secara kognitif dan fisik. Memilih model yang tepat untuk meningkatkan potensi yang dimiliki anak usia dini sangatlah penting sehingga dapat menggalih kemampuan anak usia dini seutuhnya, salah memilih metode pembelajaran merupakan musibah besar yang akan dihadapi mereka nantinya. Joyce dan Weill (Huda, 2013: 73) mendeskripsikan "model pengajaran sebagai rencana atau pola yang dapat digunakan untuk membentuk kurikulum, mendesain materi-materi instruksional, dan memandu proses pengajaran di ruang kelas atau setting yang berbeda". Hal ini sejalan Trianto (2007: 1) menjelaskan "model pembelajaran sebagai suatu perencanaan/pola yang digunakan sebagai pedoman dalam merencanakan pembelajaran di kelas atau pembelajaran tutorial".

Model pembelajaran sebagai suatu cara yang sistematis dalam mengidentifikasi, mengembangkan, dan mengevaluasi seperangkat materi dan strategi yang diarahkan untuk mencapai tujuan pendidikan. Mengindikasikan bahwa guru sebagai perancang pembelajaran di kelas hendaknya mengenal berbagai model pembelajaran yang kemudian dipilih dan diterapkan sesuai dengan situasi atau setting pembelajaran yang tepat. Salah satu model yang digunakan yakni model Snowball throwing. Model pembelajaran Snowball throwing merupakan salah satu metode pembelajaran yang dikembangkan berdasarkan pendekatan kontekstual (CTL). Edy Syahputra (2020: 26) mengatakan "Strategi pembelajaran Snowball throwing (ST) atau juga sering dikenal dengan snowball figh merupakan pembelajaran yang diadopsi pertama kali dari game fisika dimana segumpalan salju dengan maksud memukul orang lain, dalam konteks pembalajaran snowball throwing diterapkan dengan melemparkan segumpalan kertas untuk menunjukan siswa yang diharuskan menjawab soal dari guru.

Menurut Rusman (Rusman, 2013: 40) mengatakan bahwa strategi snowball throwing ini adalah "informasi materi secara umum, membentuk kelompok pemanggilan ketua dan diberi tugas dan membahas materi tertentu dikelompok, bekerja kelompok, tiap kelompok menuliskan pertanyaan dan diberikan kepada kelompok lain, kelompok lain menjawab secara bergantian, penyimpulan, evaluasi dan refleksi”. Upaya yang tepat bagi guru dimasa sekarang ini dalam rangka mencetak siswa-siswi menjadi generi yang bisa bersaing dalam menghadapi revolusi industri 4.0, harapannya adalah bahwa siswa tidak hanya mahir dalam satu aspek saja tapi tentunya terampil dalam melakukan berbagai keahlian.

Ada tiga aspek besar yang harus dicapai oleh murid dalam proses pembelajar yaitu ranah afektif, kognitif dan psikomotorik. Wina Sanjaya (2010: 14) menjelaskan bahwa seorang guru perlu memiliki kemampuan merancang dan mengimplementasikan berbagai strategi pembelajaran yang dianggap cocok dengan minat dan bakat serta sesuai dengan taraf perkembangan siswa.

Diperkuat juga oleh Benny A. Pribadi (2013: 18) "pemilihan dan penerapan desain model pembelajaran menjadi salah satu faktor penentu keberhasilan penguasaan kompetensi siswa”. Menurut Jumaris aspek-aspek perkembangan kognitif anak usia Taman Kanak-kanak berada dalan fase pra-operasional yag mencakup 3 aspek diantaranya adalah: 1) Berfikir simbolis, yaitu kemampuan untuk berfikir tentang objek dan peristiwa walaupun objek peristiwa tersebut tidak hadir secara fisik ( nyata ) dihadapan anak. 2) Berfikir egosentris, yaitu cara berfikir tentang benar atau tidak benar, setuju atau tidak setuju, berdasarkan sudut pandang sendiri. 3) Berfikir intuitif, yaitu kemampuan untuk menciptakan sesuatu, seperti menggambar atau menyusun balok, akan tetapi tidak mengetahui dengan pasti alasan melakukan ( Jamaris, 2006:23).

Menurut Piaget (Jahja, 2013: 124) dalam teori perkembangan kognitifnya mengidentifikasi 4 faktor yang sangat berpengaruh, yaitu: (1) kematangan biologis; (2) aktivitas fisik; (3) pengalaman-pengalaman sosial; dan (4) penyeimbangan (ekuilibrasi). Perkembangan adalah proses atau tahapan pertumbuhan kearah yang lebih maju. (Kristianti et al., 2018), (Syah, 2001: 41). Salah satu faktor-faktor perkembangan 
1313 Pengaruh Model Pembelajaran Snowball Throwing Terhadap Kemampuan Aspek Kognitif dan Motorik Anak Usia Dini - Lasma Roha Sitompul, Tien Rafida, Humaidah Br. Hasibuan

DOI: https://doi.org/10.31004/basicedu.v6i1.2152

psikomotorik anak usia dini yakni faktor orang tua, gen orang tua, lingkungan, interior ruang belajar, warna. Lingkungan yang mempengaruhi perkembangan psikomotorik anak adalah sekolah. Sekolah merupakan lembaga pendidikan formal yang secara sistematis melaksanakan program bimbingan, pengajaran dan latihan dalam rangka membantu siswa agar mampu mengembangkan potensinya, baik yang menyangkut aspek moralspiritual, intelektual, emosional, maupun sosial (Yusuf, 2006: 54).

Masa anak usia dini yang lebih dikenal dengan masa bermain, segalanya bagi mereka adalah bermain, makan sambil bermain, mandi sambil bermain bahkan belajar juga sambil bermain. Pada posisi seperti ini seorang guru yang kreatif harus mampu memasukkan materi materi pelajaran dalam suasana bermain tersebut. Banyak guru yang hanya mengunakan metode bernyanyi, metode bercerita, metode game dan lain-lain yang pembelajarannya lebih terfokus kepada guru itu sendiri. Sekolah RA Aisyah Az-zahrah adalah salah satu sekolah yang banyak diminati di kecamatan Medan Johor.

Penelitian yang hampir sama dengan penelitian ini pernah diteliti oleh Luk Luk Atul Fuah (2017) hasil penelitian ini menunjukkan bahwa penggunaan metode Snowball throwing dapat meningkatkan hasil belajar siswa. Hal ini dapat dilihat semakin meningkatnya hasil belajar siswa dari setiap siklusnya yaitu siklus I siswa yang tuntas belajar 14 siswa atau $70 \%$, dengan nilai rata-rata 72,25. Sedangkan untuk penilaian rubik pembuatan buklet susu dan presentasi buklet, terdapat 16 siswa mendapat kriteria penilaian (baik) dengan skor nilai 3 total skor 48, pembuatan buklet susu, Sedangkan dalam presentasi buklet susu terdapat 18 siswa mendapatkan nilai presentasi (sangat baik) dengan skor nilai 3 total skor 54. Pada siklus II meningkat menjadi 20 siswa atau $100 \%$ tuntas belajar dengan nilai rata-rata 82,8. Penilaian rubik membuat bros semua siswa kelas IVA tuntas mendapatkan nilai 4 (Sangat Baik) total skor 80. Nilai akhir hasil belajar siswa siklus I dan siklusII dengan metode Snowball throwing meningkat.

Hasil observasi awal ditemukan bahwa jumlah siswa di sekolah ini cukup banyak dibuktikan dengan adanya tiga rombel disetiap tahun, lingkungan sekolah sangat luas namun fasilitas sarana bermain belum memadai di buktikan anak-anak masih antri untuk mendapatkan giliran bermain dari sebuah alat permainan, dalam observasi peneliti tenaga pendidik di sekolah ini lebih di dominasi oleh guru yang tidak jurusan PIAUD, dan mereka bergabung dalam sebuah komunitas IGRA (Ikatan Guru Raudhatul Athfal) untuk mendapat pelatihan tentang pendidikan Anak Usia Dini. Dan sekarang ini ada satu guru yang sedang melanjutkan pendidikan di salah satu universitas dengan jurusan PIAUD untuk meningkatkan kompetensi di bidang pendidikan anak usia dini, guru di sekolah ini juga berusaha untuk memberikan strategi yang bervariasi salah satu strategi yang selalu dilakukan oleh guru adalah model pembelajaran snowball throwing, oleh karena itu peneliti ingin mendalami bagaimana model pembelajaran ini dilaksanakan dalam proses pembelajaran.

\section{METODE PENELITIAN}

Penelitian ini dilaksanakan di RA Aisyah Az-Zahra kelurahan Pangkalan Masyhur kecamatan Medan Johor kota Medan. Penelitian ini adalah penelitian kuantitatif eksperimen, Margono (2010: 92) mengatakan bahwa penelitian kuantitatif adalah "Suatu proses menemukan pengetahuan yang menggunakan data berupa angka sebagai alat menemukan keterangan mengenai apa yang ingin diketahui". Jenis penelitian yang digunakan adalah True Experimental Design, Sugiyono (2019: 132) "dikatakan true experimental karna dalam desain ini peneliti dapat mengontrol semua variabel luar yang mempengaruhi jalannya eksperimen. Populasi dalam penelitian ini ialah seluruh jumlah murid RA Aisya Az Zahra sebanyak 65 orang. Syahrum dan Salim (2016: 113) mengatakan "populasi adalah keseluruhan objek yang akan/ingin diteliti".

Penarikan sampel sampling purposive dengan mempertimbangkan jenis penelitian yang digunakan dimana dalam penelitian ini membutuhkan kelas kontrol dan kelas eksperimen. Kelas yang digunakan dalam penelitian ini adalah siswa kelas A yang berjumlah 30 siswa sebagai kelas kontrol dan kelas B sebagai kelas 
1314 Pengaruh Model Pembelajaran Snowball Throwing Terhadap Kemampuan Aspek Kognitif dan Motorik Anak Usia Dini - Lasma Roha Sitompul, Tien Rafida, Humaidah Br. Hasibuan

DOI: https://doi.org/10.31004/basicedu.v6i1.2152

eksperimen yang berjumlah 30 siswa. Syahrum dan Salim (2016: 113) juga mengatakan "Sampel adalah bagian dari populasi yang menjadi objek penelitian". Desain penelitian yang digunakan dalam penelitian ini adalah Pretest- Postest Control Group Design. Desain ini terdapat dua kelompok yang dipilih secara random, kemudian diberi pretest untuk mengetahui keadaan awal adakah perbedaan antara kelompok eksperimen dan kelompok kontrol.

Untuk mendapatkan data, keterangan maupun informasi yang diperlukan dalam penelitian ini, penulis menggunakan tiga macam instrumen pengumpulan data, yaitu observasi, interview atau wawancara, dan angket. Adapun teknik analisis data yang digunakan yakni pertama menggunakan statistik deskriptif yang digunakan untuk mendeskripsikan hasil belajar yang diperoleh siswa, baik kelompok eksperimen maupun kelompok kontrol. Kedua, statistik inferensial yang digunakan untuk menguji hipotesis penelitian yang diajukan dengan menghitung uji prasyarat melalui Uji normalitas yang digunakan untuk mengetahui distribusi normal atau tidak. Pengujian ini juga dilakukan untuk mengetahui data yang akan diperoleh dapat diuji dengan statistik parametrik atau statistik nonparametik. Untuk pengujian tersebut digunakan rumus Chikuadrat (Arikunto, 2016: 290).

$$
x_{2}, \text { Hitung }=\sum_{f=1}^{k} \frac{\left(o_{1-e 1}\right)^{2}}{E_{1}}
$$

Keterangan: $x 2=$ Nilai Chi-kuadrat hitung

$O i=$ Frekuensi hasil pengamatan

$E i=$ Frekuensi harapan

$\mathrm{K}=$ Banyaknya kelas.

Kriteria pengujian normal bila $x 2$ hitung lebih kecil dari $x 2$ tabel dimana $x 2$ tabel diperoleh dari daftar $x 2$ dengan $\mathrm{dk}=(\mathrm{k}-3)$ pada taraf signifikasi $\propto=0,05$. Selanjutnya dengan uji homogenitas ini dilakukan karena peneliti akan menggeneralisasikan akhir penelitian atau hipotesis ( $H O$ atau $H 1$ ) yang dicapai pada sampel terhadap populasi. Apabila data yang diperoleh homogen maka kelompok-kelompok sampel berasal dari populasi yang sama. Pengujian ini juga dilakukan untuk mengetahui uji t-test komparatif yang akan digunakan. Rumus yang akan digunakan separatedvarians atau polled varians. Untuk pengujian homogenitas data tes pemahaman konsep digunakan uji $\mathrm{F}$ dengan rumus sebagai berikut:

$F-\frac{\text { varians terbesar }}{\text { varians terbesar }}$

Kriteria pengujian adalah jika FHitung < FTabel pada taraf nyata dengan FTabel didapat dari distribusi $\mathrm{F}$ dengan derajat kebebasan masing-masing sesuai dengan $\mathrm{dk}$ pembilang dengan $\mathrm{dk}$ penyebut pada taraf $\propto=0,05$.

\section{HASIL DAN PEMBAHASAN}

\section{Hasil}

Hasil model pembelajaran snowball throwing di RA Aisyah Az-Zahra berdasarkan observasi, wawancara, dan angket yang peneliti sebar ke 20 peserta didik di RA Aisyah Az-Zahra sebagai sampel dalam penelitian ini. Diketahui bahwa siswa yang menjawab ibu guru selalu memberitahukan tujuan pembelajaran sebelum pelajaran dimulai sebanyak 18 orang (90\%), siswa yang menjawab ibu guru kadang-kadang memberitahukan tujuan pembelajaran sebelum pelajaran dimulai sebanyak 2 orang (10\%), sedangkan siswa yang menjawab ibu guru jarang memberitahukan tujuan pembelajaran sebelum pelajaran dimulai dan siswa yang menjawab ibu guru tidak pernah memberitahukan tujuan pembelajaran sebelum pelajaran dimulai tidak ada satupun responden yang memilihnya.

Materi pelajaran PAI yang disampaikan ibu guru sangat sesuai dengan tujuan pembelajaran sebanyak 16 siswa (80\%), siswa yang menjawab materi pelajaran PAI yang disampaikan ibu guru sesuai dengan tujuan pembelajaran sebanyak 3 siswa (15\%), siswa yang menjawab materi pelajaran PAI yang disampaikan ibu guru 
1315 Pengaruh Model Pembelajaran Snowball Throwing Terhadap Kemampuan Aspek Kognitif dan Motorik Anak Usia Dini - Lasma Roha Sitompul, Tien Rafida, Humaidah Br. Hasibuan

DOI: https://doi.org/10.31004/basicedu.v6i1.2152

kurang sesuai dengan tujuan pembelajaran sebanyak 1 orang $(5 \%)$ sedangkan untuk pertanyaan materi pelajaran PAI yang disampaikan ibu guru tidak sesuai dengan tujuan pembelajaran tidak ada satupun responden yang menjawabnya.

Namun untuk menguatkan asumsi tersebut maka dilakukan analisis deskripsi dengan melihat besar persentase total skor butir angket sebagai berikut:

$$
P=\frac{f}{n} \times 100 \%
$$

Keterangan:

$\mathrm{P}=$ Angka persentase

$\mathrm{f}=$ Jumlah skor

$\mathrm{n}=$ Jumlah sampel $\mathrm{x}$ jumlah angket $\mathrm{x}$ skor tertinggi $(20 \times 20 \times 54=1.600)$

Untuk menentukan tingkat persentase model pembelajaran snowball throwing di RA Aisyah Az-Zahra maka ditentukan dengan kategori persentase sebagai berikut:

$$
\begin{aligned}
& 0,00-0,19 \%=\text { Sangat Rendah } \\
& 0,20-0,39 \%=\text { Rendah } \\
& 0,40-0,59 \%=\text { Sedang } \\
& 0,60-0,79 \%=\text { Baik } \\
& 0,80-1,00 \%=\text { Sangat Baik }
\end{aligned}
$$

Berdasarkan rumus tersebut model pembelajaran snowball throwing di RA Aisyah Az-Zahra sebagai berikut:

$$
\begin{gathered}
P=\frac{1358}{1600} \times 100 \% \\
P=0,84 \%
\end{gathered}
$$

Nilai persentase diperoleh sebesar $0,84 \%$ dan nilai tersebut berada diantara interval $0,80-100 \%$ dengan kategori sangat baik. Hal ini menunjukkan bahwa model pembelajaran snowball throwing di RA Aisyah Az-Zahra sangat baik.

Diketahui bahwa tidak ada siswa kelas eksperimen yang dinyatakan tuntas pada pretest. Hasil distribusi frekuensi pretest kemampuan kognitif pada tabel di atas menunjukkan bahwa terdapat 2 peserta didik yang memperoleh skor pada interval 20-28, 3 peserta didik yang memperoleh skor pada interval 29-37, 4 peserta didik yang memperoleh skor 38-46, 2 peserta didik yang memperoleh skor pada interval 47-55, 3 peserta didik yang memperoleh skor pada interval 56-64, dan 6 peserta didik yang memeperoleh skor pada interval 65-73.

Berdasarkan hasil distribusi jika melakukan kategorisasi kemampuan kognitif siswa (kelas eksperimen) menggunakan model pembelajaran snowball throwing maka diperoleh hasil sebagai berikut:

Tabel 1. Tingkat Penguasaan Materi (Pretest) Siswa Di Kelas Eksperimen

\begin{tabular}{ccccc}
\hline Batas Kategori & Interval & Frekuensi & $\begin{array}{c}\text { Persentase } \\
(\mathbf{1 0 0 \% )}\end{array}$ & Kategori \\
\hline $\mathrm{X}<(\mu-1,0 \sigma)$ & $\mathrm{X}<34,9$ & 5 siswa & 15 & Rendah \\
\hline$(\mu-1,0 \sigma) \leq \mathrm{X}<(\mu+1,0$ & $34,9 \leq \mathrm{X}<62,6$ & 10 siswa & 50 & Sedang \\
$\sigma)$ & $62,6 \leq \mathrm{X}$ & 5 siswa & 15 & Tinggi \\
\hline$(\mu+1,0 \sigma) \leq \mathrm{X}$ & & & \\
\hline
\end{tabular}

Berdasarkan tabel di atas, maka dapat diketahui bahwa penguasaan materi prasyarat siswa berada pada kategori rendah ada 5 orang siswa dengan presentase $15 \%$. Pada kategori sedang ada 10 orang siswa dengan persentase $50 \%$ dan pada kategori tinggi ada 5 orang siswa dengan persentase sebesar $15 \%$ sehingga dapat disimpulkan bahwa hasil belajar biologi kelas eksperimen berada pada kategori sedang. 
1316 Pengaruh Model Pembelajaran Snowball Throwing Terhadap Kemampuan Aspek Kognitif dan Motorik Anak Usia Dini - Lasma Roha Sitompul, Tien Rafida, Humaidah Br. Hasibuan

DOI: https://doi.org/10.31004/basicedu.v6i1.2152

Adapun hasil distribusi frekuensi nilai postest kelas eksperimen pada kemampuan kognitif di atas menunjukkan bahwa terdapat 2 peserta didik yang memperoleh skor pada interval 70-74, 4 peserta didik yang memperoleh skor pada interval 75-79, 2 peserta didik yang memperoleh skor 80-84, 7 peserta didik yang memperoleh skor pada interval 85-89, 1 peserta didik yang memperoleh skor pada interval 90-94, dan 4 peserta didik yang memeperoleh skor pada interval 95-99. Kategorisasi kemampuan kognitif siswa (kelas eksperimen) menggunakan model pembelajaran snowball throwing maka diperoleh hasil sebagai berikut:

Tabel 1. Tingkat Penguasaan Materi (Postest) Siswa Di Kelas Eksperimen

\begin{tabular}{ccccc}
\hline Batas Kategori & Interval & Frekuensi & $\begin{array}{c}\text { Persentase } \\
\mathbf{( 1 0 0 \% )}\end{array}$ & Kategori \\
\hline $\mathrm{X}<(\mu-1,0 \sigma)$ & $\mathrm{X}<74,8$ & 2 siswa & 10 & Rendah \\
\hline $\begin{array}{c}(\mu-1,0 \sigma) \leq \mathrm{X}<(\mu+ \\
1,0 \sigma)\end{array}$ & $74,8 \leq \mathrm{X}<90,52$ & 14 siswa & 70 & Sedang \\
\hline$(\mu+1,0 \sigma) \leq \mathrm{X}$ & $90,52 \leq \mathrm{X}$ & 4 siswa & 20 & Tinggi \\
\hline
\end{tabular}

Berdasarkan tabel di atas, maka dapat diketahui bahwa penguasaan materi prasyarat siswa berada pada kategori rendah ada 2 orang siswa dengan presentase $10 \%$. Pada kategori sedang ada 14 orang siswa dengan persentase $70 \%$ dan pada kategori tinggi ada 4 orang siswa dengan persentase sebesar $20 \%$. sehingga dapat disimpulkan bahwa kemampuan kognitif anak kelas eksperimen berada pada kategori Sedang.

Nilai distribusi frekuensi pretest kemampuan motorik pada tabel di atas menunjukkan bahwa terdapat 2 peserta didik yang memperoleh skor pada interval 20-28, 3 peserta didik yang memperoleh skor pada interval 29-37, 4 peserta didik yang memperoleh skor 38-46, 2 peserta didik yang memperoleh skor pada interval 47 55, 3 peserta didik yang memperoleh skor pada interval 56-64, dan 6 peserta didik yang memeperoleh skor pada interval 65-73. Kemampuan kognitif siswa (kelas eksperimen) menggunakan model pembelajaran snowball throwing maka diperoleh hasil sebagai berikut:

Tabel 2. Tingkat Kemampuan Motorik (Pretest) Siswa Di Kelas Eksperimen

\begin{tabular}{ccccc}
\hline Batas Kategori & Interval & Frekuensi & $\begin{array}{c}\text { Persentase } \\
\mathbf{( 1 0 0 \% )}\end{array}$ & Kategori \\
\hline $\mathrm{X}<(\mu-1,0 \sigma)$ & $\mathrm{X}<34,9$ & 5 siswa & 25 & Rendah \\
\hline$(\mu-1,0 \sigma) \leq \mathrm{X}<(\mu+$ & $34,9 \leq \mathrm{X}<62,6$ & 9 siswa & 45 & Sedang \\
\hline $1,0 \sigma)$ & $62,6 \leq \mathrm{X}$ & 6 siswa & 30 & Tinggi \\
\hline$(\mu+1,0 \sigma) \leq \mathrm{X}$ & & & \\
\hline
\end{tabular}

Berdasarkan tabel di atas, maka dapat diketahui bahwa penguasaan materi prasyarat siswa berada pada kategori rendah ada 5 orang siswa dengan presentase $25 \%$. Pada kategori sedang ada 10 orang siswa dengan persentase $45 \%$ dan pada kategori tinggi ada 6 orang siswa dengan persentase sebesar $30 \%$ sehingga dapat disimpulkan bahwa kemampuan motorik anak dalam melempar bola kelas eksperimen berada pada kategori sedang.

Sedangkan hasil distribusi frekuensi postest kemampuan motorik di atas menunjukkan bahwa terdapat 3 peserta didik yang memperoleh skor pada interval 70-74, 1 peserta didik yang memperoleh skor pada interval 75-79, 4 peserta didik yang memperoleh skor $80-84,8$ peserta didik yang memperoleh skor pada interval 8589, 3 peserta didik yang memperoleh skor pada interval 90-94, dan 1 peserta didik yang memeperoleh skor pada interval 95-99.

Berdasarkan tabel distribusi di atas jika melakukan kategorisasi kemampuan motorik siswa (kelas eksperimen) menggunakan model pembelajaran snowball throwing maka diperoleh hasil sebagai berikut: 
1317 Pengaruh Model Pembelajaran Snowball Throwing Terhadap Kemampuan Aspek Kognitif dan Motorik Anak Usia Dini - Lasma Roha Sitompul, Tien Rafida, Humaidah Br. Hasibuan

DOI: https://doi.org/10.31004/basicedu.v6i1.2152

Tabel 3. Tingkat Penguasaan Kemampuan Motorik (Postest) Siswa Di Kelas Eksperimen

\begin{tabular}{ccccc}
\hline Batas Kategori & Interval & Frekuensi & $\begin{array}{c}\text { Persentase } \\
\mathbf{( 1 0 0 \% )}\end{array}$ & Kategori \\
\hline $\mathrm{X}<(\mu-1,0 \sigma)$ & $\mathrm{X}<74,8$ & 3 siswa & 15 & Rendah \\
\hline $\begin{array}{c}(\mu-1,0 \sigma) \leq \mathrm{X}<(\mu+ \\
1,0 \sigma)\end{array}$ & $74,8 \leq \mathrm{X}<90,52$ & 16 siswa & 80 & Sedang \\
\hline$(\mu+1,0 \sigma) \leq \mathrm{X}$ & $90,52 \leq \mathrm{X}$ & 1 siswa & 5 & Tinggi \\
\hline
\end{tabular}

Berdasarkan tabel di atas, maka dapat diketahui bahwa penguasaan materi prasyarat siswa berada pada kategori rendah ada 3 orang siswa dengan presentase 15\%. Pada kategori sedang ada 16 orang siswa dengan persentase $80 \%$ dan pada kategori tinggi ada 1 orang siswa dengan persentase sebesar $5 \%$. sehingga dapat disimpulkan bahwa kemampuan motorik anak kelas eksperimen berada pada kategori sedang.

Hasil model pembelajaran snowball throwing di RA Aisyah Az-Zahra berdasarkan observasi, wawancara, dan angket yang peneliti sebar ke 20 peserta didik di RA Aisyah Az-Zahra sebagai sampel dalam penelitian ini. Diketahui bahwa siswa yang menjawab ibu guru selalu memberitahukan tujuan pembelajaran sebelum pelajaran dimulai sebanyak 18 orang (90 \%), siswa yang menjawab ibu guru kadang-kadang memberitahukan tujuan pembelajaran sebelum pelajaran dimulai sebanyak 2 orang (10\%), sedangkan siswa yang menjawab ibu guru jarang memberitahukan tujuan pembelajaran sebelum pelajaran dimulai dan siswa yang menjawab ibu guru tidak pernah memberitahukan tujuan pembelajaran sebelum pelajaran dimulai tidak ada satupun responden yang memilihnya.

Materi pelajaran PAI yang disampaikan ibu guru sangat sesuai dengan tujuan pembelajaran sebanyak 16 siswa (80\%), siswa yang menjawab materi pelajaran PAI yang disampaikan ibu guru sesuai dengan tujuan pembelajaran sebanyak 3 siswa (15\%), siswa yang menjawab materi pelajaran PAI yang disampaikan ibu guru kurang sesuai dengan tujuan pembelajaran sebanyak 1 orang $(5 \%)$ sedangkan untuk pertanyaan materi pelajaran PAI yang disampaikan ibu guru tidak sesuai dengan tujuan pembelajaran tidak ada satupun responden yang menjawabnya.

Namun untuk menguatkan asumsi tersebut maka dilakukan analisis deskripsi dengan melihat besar persentase total skor butir angket sebagai berikut:

$P=\frac{f}{n} \times 100 \%$

Keterangan:

$\mathrm{P}=$ Angka persentase

$\mathrm{f}=$ Jumlah skor

$\mathrm{n}=$ Jumlah sampel $\mathrm{x}$ jumlah angket $\mathrm{x}$ skor tertinggi $(20 \times 20 \times 54=1.600)$

Untuk menentukan tingkat persentase model pembelajaran snowball throwing di RA Aisyah Az-Zahra maka ditentukan dengan kategori persentase sebagai berikut:

$0,00-0,19 \%=$ Sangat Rendah

$0,20-0,39 \%=$ Rendah

$0,40-0,59 \%=$ Sedang

$0,60-0,79 \%=$ Baik

$0,80-1,00 \%=$ Sangat Baik

Berdasarkan rumus tersebut model pembelajaran snowball throwing di RA Aisyah Az-Zahra sebagai berikut:

$$
\begin{gathered}
P=\frac{1358}{1600} \times 100 \% \\
P=0,84 \%
\end{gathered}
$$


1318 Pengaruh Model Pembelajaran Snowball Throwing Terhadap Kemampuan Aspek Kognitif dan Motorik Anak Usia Dini - Lasma Roha Sitompul, Tien Rafida, Humaidah Br. Hasibuan

DOI: https://doi.org/10.31004/basicedu.v6i1.2152

Nilai persentase diperoleh sebesar $0,84 \%$ dan nilai tersebut berada diantara interval $0,80-100 \%$ dengan kategori sangat baik. Hal ini menunjukkan bahwa model pembelajaran snowball throwing di RA Aisyah Az-Zahra sangat baik. Hasil distribusi frekuensi pretest kemampuan kognitif pada tabel di atas menunjukkan bahwa terdapat 2 peserta didik yang memperoleh skor pada interval 20-28, 3 peserta didik yang memperoleh skor pada interval 29-37, 4 peserta didik yang memperoleh skor 38-46, 2 peserta didik yang memperoleh skor pada interval 47-55, 3 peserta didik yang memperoleh skor pada interval 56-64, dan 6 peserta didik yang memeperoleh skor pada interval 65-73.

Berdasarkan kategorisasi kemampuan kognitif siswa (kelas eksperimen) menggunakan model pembelajaran snowball throwing maka diperoleh hasil sebagai berikut:

Tabel 4. Tingkat Penguasaan Materi (Pretest) Siswa Di Kelas Eksperimen

\begin{tabular}{cclrc}
\hline Batas Kategori & Interval & Frekuensi & $\begin{array}{c}\text { Persentase } \\
(\mathbf{1 0 0 \% )}\end{array}$ & Kategori \\
\hline $\mathrm{X}<(\mu-1,0 \sigma)$ & $\mathrm{X}<34,9$ & 5 siswa & 15 & Rendah \\
\hline $\begin{array}{c}(\mu-1,0 \sigma) \leq X<(\mu+1,0 \\
\sigma)\end{array}$ & $34,9 \leq \mathrm{X}<62,6$ & 10 siswa & 50 & Sedang \\
\hline$(\mu+1,0 \sigma) \leq \mathrm{X}$ & $62,6 \leq \mathrm{X}$ & 5 siswa & 15 & Tinggi \\
\hline
\end{tabular}

Berdasarkan tabel di atas, maka dapat diketahui bahwa penguasaan materi prasyarat siswa berada pada kategori rendah ada 5 orang siswa dengan presentase $15 \%$. Pada kategori sedang ada 10 orang siswa dengan persentase $50 \%$ dan pada kategori tinggi ada 5 orang siswa dengan persentase sebesar $15 \%$ sehingga dapat disimpulkan bahwa hasil belajar biologi kelas eksperimen berada pada kategori sedang.

Hasil distribusi frekuensi postest kemampuan kognitif di atas menunjukkan bahwa terdapat 2 peserta didik yang memperoleh skor pada interval 70-74, 4 peserta didik yang memperoleh skor pada interval 75-79, 2 peserta didik yang memperoleh skor 80-84, 7 peserta didik yang memperoleh skor pada interval 85-89, 1 peserta didik yang memperoleh skor pada interval 90-94, dan 4 peserta didik yang memeperoleh skor pada interval 95-99. Berdasarkan kategorisasi kemampuan kognitif siswa (kelas eksperimen) menggunakan model pembelajaran snowball throwing maka diperoleh hasil sebagai berikut:

Tabel 5 Tingkat Penguasaan Materi (Postest) Siswa Di Kelas Eksperimen

\begin{tabular}{ccccc}
\hline Batas Kategori & Interval & Frekuensi & $\begin{array}{c}\text { Persentase } \\
(\mathbf{1 0 0 \% )}\end{array}$ & Kategori \\
\hline $\mathrm{X}<(\mu-1,0 \sigma)$ & $\mathrm{X}<74,8$ & 2 siswa & 10 & Rendah \\
\hline $\begin{array}{c}(\mu-1,0 \sigma) \leq \mathrm{X}<(\mu+ \\
1,0 \sigma)\end{array}$ & $74,8 \leq \mathrm{X}<90,52$ & 14 siswa & 70 & Sedang \\
\hline$(\mu+1,0 \sigma) \leq \mathrm{X}$ & $90,52 \leq \mathrm{X}$ & 4 siswa & 20 & Tinggi \\
\hline
\end{tabular}

Berdasarkan tabel di atas, maka dapat diketahui bahwa penguasaan materi prasyarat siswa berada pada kategori rendah ada 2 orang siswa dengan presentase $10 \%$. Pada kategori sedang ada 14 orang siswa dengan persentase $70 \%$ dan pada kategori tinggi ada 4 orang siswa dengan persentase sebesar $20 \%$. sehingga dapat disimpulkan bahwa kemampuan kognitif anak kelas eksperimen berada pada kategori Sedang.

Berdasarkan hasil penelitian yang dilakukan di RA Aisyah Az-Zahra penulis mengumpulkan data dari instrumen tes melalui nilai kemampuan motorik pretest-posttest. Hasil distribusi frekuensi pretest kemampuan motorik pada tabel di atas menunjukkan bahwa terdapat 2 peserta didik yang memperoleh skor pada interval 20-28, 3 peserta didik yang memperoleh skor pada interval 29-37, 4 peserta didik yang memperoleh skor 3846, 2 peserta didik yang memperoleh skor pada interval 47-55, 3 peserta didik yang memperoleh skor pada interval 56-64, dan 6 peserta didik yang memeperoleh skor pada interval 65-73. 
1319 Pengaruh Model Pembelajaran Snowball Throwing Terhadap Kemampuan Aspek Kognitif dan Motorik Anak Usia Dini - Lasma Roha Sitompul, Tien Rafida, Humaidah Br. Hasibuan

DOI: https://doi.org/10.31004/basicedu.v6i1.2152

Tabel 6 Tingkat Kemampuan Motorik (Pretest) Siswa Di Kelas Eksperimen

\begin{tabular}{ccccc}
\hline Batas Kategori & Interval & Frekuensi & $\begin{array}{c}\text { Persentase } \\
(\mathbf{1 0 0 \% )}\end{array}$ & Kategori \\
\hline $\mathrm{X}<(\mu-1,0 \sigma)$ & $\mathrm{X}<34,9$ & 5 siswa & 25 & Rendah \\
\hline$(\mu-1,0 \sigma) \leq \mathrm{X}<(\mu+1,0$ & $34,9 \leq \mathrm{X}<62,6$ & 9 siswa & 45 & Sedang \\
$\sigma)$ & $62,6 \leq \mathrm{X}$ & 6 siswa & 30 & Tinggi \\
\hline$(\mu+1,0 \sigma) \leq \mathrm{X}$ & & &
\end{tabular}

Berdasarkan tabel di atas, maka dapat diketahui bahwa penguasaan materi prasyarat siswa berada pada kategori rendah ada 5 orang siswa dengan presentase $25 \%$. Pada kategori sedang ada 10 orang siswa dengan persentase $45 \%$ dan pada kategori tinggi ada 6 orang siswa dengan persentase sebesar $30 \%$ sehingga dapat disimpulkan bahwa kemampuan motorik anak dalam melempar bola kelas eksperimen berada pada kategori sedang.

Sedangkan hasil distribusi frekuensi postest kemampuan motorik di atas menunjukkan bahwa terdapat 3 peserta didik yang memperoleh skor pada interval 70-74, 1 peserta didik yang memperoleh skor pada interval 75-79, 4 peserta didik yang memperoleh skor $80-84,8$ peserta didik yang memperoleh skor pada interval 85 89, 3 peserta didik yang memperoleh skor pada interval 90-94, dan 1 peserta didik yang memeperoleh skor pada interval 95-99. Berdasarkan tabel distribusi di atas jika melakukan kategorisasi kemampuan motorik siswa (kelas eksperimen) menggunakan model pembelajaran snowball throwing maka diperoleh hasil sebagai berikut:

Tabel 7 Tingkat Penguasaan Kemampuan Motorik (Postest) Siswa Di Kelas Eksperimen

\begin{tabular}{ccccc}
\hline Batas Kategori & Interval & Frekuensi & $\begin{array}{c}\text { Persentase } \\
\mathbf{( 1 0 0 \% )}\end{array}$ & Kategori \\
\hline $\mathrm{X}<(\mu-1,0 \sigma)$ & $\mathrm{X}<74,8$ & 3 siswa & 15 & Rendah \\
\hline $\begin{array}{c}(\mu-1,0 \sigma) \leq \mathrm{X}<(\mu+ \\
1,0 \sigma)\end{array}$ & $74,8 \leq \mathrm{X}<90,52$ & 16 siswa & 80 & Sedang \\
\hline$(\mu+1,0 \sigma) \leq \mathrm{X}$ & $90,52 \leq \mathrm{X}$ & 1 siswa & 5 & Tinggi \\
\hline
\end{tabular}

Berdasarkan tabel di atas, maka dapat diketahui bahwa penguasaan materi prasyarat siswa berada pada kategori rendah ada 3 orang siswa dengan presentase $15 \%$. Pada kategori sedang ada 16 orang siswa dengan persentase $80 \%$ dan pada kategori tinggi ada 1 orang siswa dengan persentase sebesar $5 \%$. sehingga dapat disimpulkan bahwa kemampuan motorik anak kelas eksperimen berada pada kategori sedang.

Distribusi frekuensi pretest kemampuan kognitif pada tabel di atas menunjukkan bahwa terdapat 1 peserta didik yang memperoleh skor pada interval 20-28, 1 peserta didik yang memperoleh skor pada interval 29-37, 5 peserta didik yang memperoleh skor 38-46, 4 peserta didik yang memperoleh skor pada interval 47 55, 5 peserta didik yang memperoleh skor pada interval 56-69, dan 4 peserta didik yang memeperoleh skor pada interval 70-75.

Berdasarkan tabel distribusi di atas jika melakukan kategorisasi kemampuan kognitif siswa (kelas eksperimen) menggunakan model pembelajaran snowball throwing maka diperoleh hasil diketahui bahwa penguasaan materi prasyarat siswa berada pada kategori rendah ada 1 orang siswa dengan presentase $5 \%$. Pada kategori sedang ada 15 orang siswa dengan persentase $75 \%$ dan pada kategori tinggi ada 4 orang siswa dengan persentase sebesar 20\% sehingga dapat disimpulkan bahwa kemampuan kognitif kelas kontrol preetest berada pada kategori sedang.

Nilai distribusi frekuensi pretest kemampuan kognitif pada tabel di atas menunjukkan bahwa terdapat 3 peserta didik yang memperoleh skor pada interval 30-35, 1 peserta didik yang memperoleh skor pada interval 36-40, 1 peserta didik yang memperoleh skor 41-46, 1 peserta didik yang memperoleh skor pada interval $47-$ 
1320 Pengaruh Model Pembelajaran Snowball Throwing Terhadap Kemampuan Aspek Kognitif dan Motorik Anak Usia Dini - Lasma Roha Sitompul, Tien Rafida, Humaidah Br. Hasibuan

DOI: https://doi.org/10.31004/basicedu.v6i1.2152

55, 9 peserta didik yang memperoleh skor pada interval 56-69, dan 5 peserta didik yang memeperoleh skor pada interval 70-80.

Berdasarkan tabel distribusi di atas jika melakukan kategorisasi kemampuan kognitif siswa (kelas kontrol) tanpa menggunakan model pembelajaran snowball throwing maka diperoleh hasil diketahui bahwa kemampuan kognitif siswa berada pada kategori rendah ada 3 orang siswa dengan presentase $15 \%$. Pada kategori sedang ada 12 orang siswa dengan persentase $60 \%$ dan pada kategori tinggi ada 5 orang siswa dengan persentase sebesar $25 \%$. sehingga dapat disimpulkan bahwa kemampuan kognitif anak kelas kontrol berada pada kategori sedang.

Diketahui bahwa ada $3(15 \%)$ siswa kelas kontrol yang dinyatakan tuntas pada pretes dan $13(75 \%)$ siswa tidak lulus. Berdasarkan hasil tersebut, dapat ditarik kesimpulan bahwa secara umum kemampuan motorik siswa belum baik terkait melempar dan menangkap bola. Distribusi frekuensi pretest kemampuan motorik menunjukkan bahwa terdapat 3 peserta didik yang memperoleh skor pada interval 40-44, 1 peserta didik yang memperoleh skor pada interval 45-47, 1 peserta didik yang memperoleh skor 48-50, 3 peserta didik yang memperoleh skor pada interval 51-59, 9 peserta didik yang memperoleh skor pada interval 60-69, dan 3 peserta didik yang memeperoleh skor pada interval 70-75.

Diketahui bahwa kemampuan motorik siswa berada pada kategori rendah ada 3 orang siswa dengan presentase $15 \%$. Pada kategori sedang ada 14 orang siswa dengan persentase $80 \%$ dan pada kategori tinggi ada 3 orang siswa dengan persentase sebesar 15\% sehingga dapat disimpulkan kemampuan motorik siswa kelas kontrol berada pada kategori sedang. Distribusi frekuensi postest kemampuan kognitif di atas menunjukkan bahwa terdapat 2 peserta didik yang memperoleh skor pada interval 40-46, 2 peserta didik yang memperoleh skor pada interval 47-53, 2 peserta didik yang memperoleh skor 54-60, 2 peserta didik yang memperoleh skor pada interval 61-67, 2 peserta didik yang memperoleh skor pada interval 68-74, dan 10 peserta didik yang memeperoleh skor pada interval 75-80.

Diketahui bahwa penguasaan materi prasyarat siswa berada pada kategori rendah ada 2 orang siswa dengan presentase $10 \%$. Pada kategori sedang ada 8 orang siswa dengan persentase $40 \%$ dan pada kategori tinggi ada 10 orang siswa dengan persentase sebesar $80 \%$. sehingga dapat disimpulkan bahwa kemampuan motorik siswa kelas kontrol berada pada kategori tinggi.

Berdasarkan hasil hipotesis di atas maka diperoleh thitung $=6,44$ maka thitung $>$ ttabel $(6,44>2,093)$, Dengan demikian keputusan pengujian ini menolak $\mathrm{H}_{0}$ dan menerima $\mathrm{H}_{1}$ yang berarti terdapat pengaruh yang signifikan antara model pembelajaran snowball shrowing terhadap kemampuan kognitif anak usia dini di RA Aisyah Az-Zahra.

Berdasarkan hasil hipotesis di atas maka diperoleh thitung $=5,96$ maka thitung $>$ ttabel $(5,96>2,093)$, Dengan demikian keputusan pengujian ini menolak $\mathrm{H}_{0}$ dan menerima $\mathrm{H}_{1}$ yang berarti terdapat pengaruh yang antara model pembelajaran snowball shrowing terhadap kemampuan motorik anak usia dini di RA Aisyah AzZahra.

\section{Pembahasan}

Berdasarkan hasil pengujian hipotesis dan pembahasan, maka temuan dalam penelitian ini menyatakan bahwa terdapat pengaruh yang signifikan perilaku prososial anak dengan menggunakan model pembelajaran snowball pada kemampuan kognitif siswa RA Aisyah Az-zahra tergolong baik dan termasuk dalam kategori sedang. Hal ini terbukti dengan nilai rata-rata yang mengalami peningkatan secara signifikan, dimana perolehan nilai rata-rata pretest yaitu sebesar 48,75 namun setelah diajar menggunakan model pembelajaran snowball throwing diperoleh nilai rata-rata 82,64.

Berdasarkan hasil penelitian yang dilakukan di RA Aisyah Az-Zahra penulis mengumpulkan data dari instrumen tes melalui nilai kemampuan motorik pretest-posttest peserta didik sebagai berikut pretest kemampuan motorik pada tabel di atas menunjukkan bahwa terdapat 2 peserta didik yang memperoleh skor 
1321 Pengaruh Model Pembelajaran Snowball Throwing Terhadap Kemampuan Aspek Kognitif dan Motorik Anak Usia Dini - Lasma Roha Sitompul, Tien Rafida, Humaidah Br. Hasibuan

DOI: https://doi.org/10.31004/basicedu.v6i1.2152

pada interval 20-28, 3 peserta didik yang memperoleh skor pada interval 29-37, 4 peserta didik yang memperoleh skor 38-46, 2 peserta didik yang memperoleh skor pada interval 47-55, 3 peserta didik yang memperoleh skor pada interval 56-64, dan 6 peserta didik yang memeperoleh skor pada interval 65-73. Setelah dilakukan pembelajaran melalui model snowball throwing postest kemampuan motorik di atas menunjukkan bahwa terdapat 3 peserta didik yang memperoleh skor pada interval 70-74, 1 peserta didik yang memperoleh skor pada interval 75-79, 4 peserta didik yang memperoleh skor 80-84, 8 peserta didik yang memperoleh skor pada interval 85-89, 3 peserta didik yang memperoleh skor pada interval 90-94, dan 1 peserta didik yang memeperoleh skor pada interval 95-99. pada kategori rendah ada 3 orang siswa dengan presentase $15 \%$. Pada kategori sedang ada 16 orang siswa dengan persentase $80 \%$ dan pada kategori tinggi ada 1 orang siswa dengan persentase sebesar $5 \%$. sehingga dapat disimpulkan bahwa kemampuan kognitif anak kelas eksperimen berada pada kategori sedang.

Berdasarkan hasil penelitian yang dilakukan di RA Aisyah Az-Zahra penulis mengumpulkan data dari instrumen tes melalui nilai kemampuan kognitif pretest-posttest peserta didik sebagai berikut frekuensi pretest kemampuan kognitif pada tabel di atas menunjukkan bahwa terdapat distribusi frekuensi pretest kemampuan kognitif pada tabel di atas menunjukkan bahwa terdapat 3 peserta didik yang memperoleh skor pada interval 30-35, 1 peserta didik yang memperoleh skor pada interval 36-40, 1 peserta didik yang memperoleh skor 4146, 1 peserta didik yang memperoleh skor pada interval 47-55, 9 peserta didik yang memperoleh skor pada interval 56-69, dan 5 peserta didik yang memeperoleh skor pada interval 70-80. kategori rendah ada 3 orang siswa dengan presentase $15 \%$. Pada kategori sedang ada 12 orang siswa dengan persentase $60 \%$ dan pada kategori tinggi ada 5 orang siswa dengan persentase sebesar 25\%. Sehingga dapat disimpulkan bahwa kemampuan kognitif anak kelas kontrol berada pada kategori sedang. Sedangkan frekuensi postest kemampuan kognitif di atas menunjukkan bahwa terdapat 2 peserta didik yang memperoleh skor pada interval 40-46, 2 peserta didik yang memperoleh skor pada interval 47-53, 2 peserta didik yang memperoleh skor 5460, 2 peserta didik yang memperoleh skor pada interval 61-67, 2 peserta didik yang memperoleh skor pada interval 68-74, dan 10 peserta didik yang memeperoleh skor pada interval 75-80. kategori rendah ada 2 orang siswa dengan presentase $10 \%$. Pada kategori sedang ada 8 orang siswa dengan persentase $40 \%$ dan pada kategori tinggi ada 10 orang siswa dengan persentase sebesar $80 \%$. sehingga dapat disimpulkan bahwa kemampuan motorik siswa kelas kontrol berada pada kategori tinggi.

Pengaruh yang signifikan antara model pembelajaran snowball throwing terhadap kemampuan aspek kognitif dan motorik anak usia dini di RA Aisyah Az-zahra. Secara teoritis dapat dipahami bahwa model pembelejaran snowball throwing dianggap mampu membangun siswa menjadi lebih aktif dalam pembelajaran yang dapat menstimulasi keterlibatan siswa terhadap materi pelajaran yang diberikan. Strategi ini merupakan aktifitas kolaboratif yang dapat mengajak siswa untuk terlibat dalam materi pembelajaran langsung. Strategi ini dapat menumbuhkan kerja sama kelompok dan saling bertukar pendapat. Dengan demikian dari hasil penelitian yang telah diperoleh dan dianalisis maka dapat disimpulkan bahwa terdapat pengaruh model pembelajaran snowball throwing pada kemampuan aspek kognitif dan motorik anak usia dini di RA Aisyah Az-zahra.

\section{KESIMPULAN}

Model pembelajaran snowball throwing di RA Aisyah Az-zahra Medan Johor, nilai persentase diperoleh sebesar 0,84 \% dan nilai tersebut berada diantara interval 0,80 - 100 \% dengan kategori sangat baik, hal ini menunjukkan bahwa model pembelajaran snowball throwing di RA Aisyah Az-zahra sangat baik. Pengaruh model pembelajaran snowball throwing terhadap kemampuan aspek kognitif anak usia dini di RA Aisyah Az-zahra Medan Johor s berpengaruh. Hal ini dilihat dari hasil hipotesis diperoleh $t$ hitung $=6,44$ maka thitung > ttabel $(6,44>2,093)$. Dengan demikian keputusan pengujian ini menolak H0 dan menerima H1 
1322 Pengaruh Model Pembelajaran Snowball Throwing Terhadap Kemampuan Aspek Kognitif dan Motorik Anak Usia Dini - Lasma Roha Sitompul, Tien Rafida, Humaidah Br. Hasibuan

DOI: https://doi.org/10.31004/basicedu.v6i1.2152

yang berarti terdapat pengaruh yang signifikan antara model pembelajaran snowball shrowing terhadap kemampuan kognitif anak usia dini di RA Aisyah Az-Zahra. Pengaruh model pembelajaran snowball throwing terhadap kemampuan aspek motorik anak usia dini di RA Aisyah Az-Zahra Medan Johor hasil hipotesis di atas maka diperoleh thitung $=5,96$ maka thitung $>$ ttabel $(5,96>2,093)$, Dengan demikian keputusan pengujian ini menolak $\mathrm{H} 0$ dan menerima $\mathrm{H}_{1}$ yang berarti terdapat pengaruh yang antara model pembelajaran snowball shrowing terhadap kemampuan motorik anak usia dini di RA Aisyah Az-Zahra.

\section{UCAPAN TERIMA KASIH}

Terima kasih kepada RA RA Aisyah Az-Zahra Medan Johor yang telah membantu peneliti, sehingga penelitian ini dapat terlaksana.

\section{DAFTAR PUSTAKA}

A.Pribadi, B. (2013). Model Desain Sistem Pembelajaran. Jakarta: Dian Rakyat.

Arikunto, S. (2016). Prosedur Penelitian: Suatu Pendekatan Praktik. Jakarta: Rineka Cipta.

Edy, S. (2020). Snowball throwing Tingkatan Minat Dan Hasil Belajar. Sukabumi: Haura Publishing.

Fuah, L. L. A. (2017). Penggunaan Metode Pembelajaran Snowball throwing Untuk Meningkatkan Hasil Belajar Tematik Tema Makananku Sehat Dan Bergizi Pada Siswa Kelas Iv Min Manggarwetan Kecamatan Godong Kabupaten Grobogan. Iain Salatiga.

Hasbullah. (2016). Model Pengembangan Kurikulum Paud, Jurnal Pendidikan Guru Raudlatul Athfal AṣSibyan, Vol.1, No.1.

Hidayah \& Rohmatun. N. (2015). Pendidikan Anak Usia Dini Perspektif Ki Hajar Dewantara. Al-Mabsut, Jurnal Studi Islam Dan Sosial, Vol 9, No 2.

Huda, M. (2013). Model-Model Pengajaran Dan Pembelajaran Cet:1. Yogyakarta: Pustaka Belajar.

Jahja, Y. (2013). Psikologi Perkembangan. Jakarta: Prenada Media.

Khadijah \& Amelia, Nur. (2020). Perkembangan Keterampilan Prakarya Anak Usia Dini, Medan: Perdana Publishing.

Kristianti, I. A. P. C., Gading, I. K., \& Antara, P. A. (2018). Pengaruh Model Pembelajaran Snowball throwing Terhadap Perilaku Prososial Anak Kelompok B Di Gugus Ii. Jurnal Pendidikan Anak Usia Dini Universitas Pendidikan Ganesha, 6(2), 230-240.

Margono. (2010). Metodologi Penelitian Pendidikan. Jakarta: Pt. Rineka Cipta.

Mursidi. (2017). Pengembangan Pembelajaran Paud. Bandung:Pt. Remaja Rosdakarya.

Rahman, H, M. \& Kencana, R. (2020). Implementasi Model Pembelajaran Kooperatif Dalam Meningkatkan Perkembangan Sosial Anak Usia Dini. Musamus Journal Of Primary Education. Vol. 2 No 2.

Rohimah, N. (2016). Bermain Dan Pemanfaatannya Dalam Perkembangan Anak Usia Dini, Jurnal Tarbawi Vol. 13. No. 2.

Rusman. (2013). Metode-Metode Pembelajran: Mengembangkan Profesionalisme Guru. Jakarta: Pt Raja Grafindo Persada.

Salim, \& Syahrum. (2016). Metode Penelitian Kualitatif. Bandung: Cita Pustaka Media.

Sanjaya, W. (2010). Strategi Pembelajaran. Yogyakarta: Media Abadi.

Sugiyono. (2019). Metode Penelitian Kuantitatif, Kualitatif, Dan R\&D. Bandung: Alfabeta. 
1323 Pengaruh Model Pembelajaran Snowball Throwing Terhadap Kemampuan Aspek Kognitif dan Motorik Anak Usia Dini - Lasma Roha Sitompul, Tien Rafida, Humaidah Br. Hasibuan DOI: https://doi.org/10.31004/basicedu.v6i1.2152

Syah, M. (2001). Psikologi Pendidikan Dengan Pendekatan Baru. Bandung: Pt. Remaja Rosdakarya.

Trianto. (2007). Model-Model Pembelajaran Inovatif Berorientasi Kontruktivistik. Jakarta: Prestasi Pustaka. Yusuf, S. (2006). Psikologi Perkembangan Anak Dan Remaja. Bandung: Remaja Rosdakarya. 